\title{
Sundanese Karawitan and Modernity
}

\author{
Mohamad Rudiana \\ Postgraduate Program ISI Yogyakarta \\ Jalan Soryodiningratan No. 8 Yogyakarta
}

\begin{abstract}
ABSTRAK
Karawitan sebagai seni tradisi hingga saat ini masih digemari masyarakat. Pada konteks keberadaannya di dalam masyarakat sekarang, seni tradisi dihadapkan pada semacam paradoks. Di satu pihak, untuk bertahan hidup, ia membutuhkan daya tarik dan pesona, berupa inovasi-inovasi kreatif yang bersumber dari tradisi itu sendiri; di pihak lain, jika seniman melakukan perubahan dan inovasi dari tradisi, maka sama artinya dengan menghapus tradisi itu sendiri, karena tradisi tidak menolelir transformasi. Metode yang digunakan pada penelitian ini bersifat kualitatif dengan landasan berfikir fenomenologis interpretif yang berorientasi pada kebenaran yang bersifat subjektif dari sumber penelitian. Pengumpulan data dilakukan dengan menggunakan wawancara mendalam (in-depth interview) sebagai teknik yang utama dalam penelitian ini. Hasilnya adalah saat ini ada kecenderungan proses kombinasi baru antara seni tradisi dengan seni modern. Modernisasi bukan untuk dihindari, melainkan harus dimanfaatkan untuk memutakhirkan kesenian tradisional. Upaya ini sebenarnya penyiasatan agar kesenian tradisional tetap bertahan. Banyak kesenian tradisional yang dapat bertahan justru karena mengikuti arus modernisasi dan globalisasi itu.
\end{abstract}

Kata kunci: karawitan, seni tradisi sunda, seni modern, inovasi

\begin{abstract}
As a traditional art form, karawitan is still popular among the Sundanese community. Contextually, there is a paradox within the presence of this traditional art form in today's society: to survive in the modern world, traditional art needs appeal and charm in terms of creative innovations that come from the tradition itself; on the other hand, changes and improvements of the tradition are in fact erasing the tradition itself, because tradition does not tolerate transformation. The method used in this research is qualitative with phenomenological interpretive thinking foundations oriented towards the subjective nature of truth from research sources. Collecting data using in-depth interviews is the main method used for data collection. Nowadays there is a tendency to combine traditional arts with modern arts. Modernization is not to be avoided. Instead, it should be used to update traditional art. These efforts are actually strategies to preserve traditional art. Many traditional arts survive because they follow the stream of modernization and globalization.
\end{abstract}

Keywords: karawitan, traditional art form, modern art, innovation 


\section{INTRODUCTION}

Cultural problems of Sundanese society, as well as Indonesian people in general, is indicated by the process of cultural and local tradition alienation or exclusion (marginalization) by their own ethnic community. This marginalization occurs as a result of the advances of the era, such as the use of patterns of time division; the present Sundanese people now usually use the system of international time division and Islamic prayer times in their daily life.

Modernization and globalization have shifted the indigenous local culture to the periphery of culture and to the corners of society's collective memory. On the one hand, the rationalization and development of science and technology have modernized Sundanese life and facilitated their lives. On the other hand, the risk is enormous, namely the destruction of social institutions, religious institutions and the fading of Sundanese tradition. This can be seen from the fact that many traditional arts have been forgotten by their people.

In Sundanese culture, sounds cannot be separated from habits or traditions that are commonly practiced by the people. The sounds can be presented as kalangenan or games played by both adults and children at different times and places, for example, tutunggulan is usually done when the full moon rises, ngadu drum is performed during the fasting month. However, in general, it is Sundanese musical karawitan that is wellknown as Sundanese traditional music.

Sundanese karawitan is generally divided into three types, namely karawitan sekar, karawitan gending and karawitan sekar gending. Karawitan sekar is all kinds of karawitan performance that use only human voice (vocal) media. Karawitan gending is a type of karawitan that use only sounds of musical instruments. Gending can also be interpreted as a song that is performed by instruments. In other words, karawitan gending is instrumental. While karawitan sekar gending is a combination of both (Soepandi, 1995).

In addition to karawitan, there are still many Sundanese musical art forms such as beluk, wawacan, ciawian, cigawiran, belentuk ngapung, rengkong, etc. Those are a few of traditional musical forms that are rarely or never performed anymore in the arena (Hermawan, 2006: 1). The forms of traditional music mentioned above are further described in the study entitled Bandungan: an Alternative Form of Tembang and Kawih Creativity by Deni Hermawan (2006) as a result of decreasing level of public demands for particular performing arts due to their irrelevance with people's way of thinking, inappropriateness with current situation and condition of society. All of these may lessen people's knowledge about Sundanese karawitan that is also worsened by the limited number of sources discussing it.

People's limited knowledge about Sundanese karawitan is closely related to limited media that give information about Sundanese karawitan. It can be said that there is lack of print and electronic media that specifically covers Sundanese karawitan, in the form of bulletins, magazines, newspapers, or tabloids, up to television programs.

Since young people as part of society are rarely exposed to traditional arts, they now take global culture as their own culture. Therefore, traditional art and culture are considered as foreign things. This is similar to what was revealed by Soedarso Sp (1991: 26):

The most obvious impact of the influx of foreign cultures, especially the West to Indonesia, is the declining interest of the people, especially the younger generation towards something ethnic. This is due to the weak understanding of the ins and outs of the arts itself.

As we know, culture is constantly changing. Among a number of traditional music that survive and continue to grow, 
there are so many other traditional arts that slowly ebb and eventually perish. This issue has prompted many traditional artists to engage in creativity with revitalization concept, such as presenting traditional music within a new package. For example, patareman performs beluk as a part of a new composition (Hermawan, 2002: 29). This effort can never bring the arts of beluk back to life because life indeed has changed (for example, the paddy system has used tractor so that farmers no longer perform beluk when they plow the paddy). Another example is bandungan developed by Dasentra (Daya seni tradisi or Power of Arts Tradition) Bandung because it was inspired by tembang sunda cianjuran that still exists (Hermawan, 2006: 3). This effort does not change the arts of tembang sunda cianjuran because its people keep embracing and developing. However, what is done by Dasentra Ban-dung (patareman and bandungan) is still in the corridor of Sundanese Traditional Arts.

In the conclusion of his research, Hermawan (2006: 17) mentions that Dasentra's effort in the form of tembang bandungan is the result of creativity that jumps far away from its original source and automatically offers innovative things (new) in it.

Another example related to innovative action developed by artists of tradition is campursari. In terms of music, campursari is able to combine traditional music (gamelan), keroncong/langgam and pop music with Western musical instruments. Although debatable, campursari has developed in society (especially in Central Java) since the 1980s, and now this music genre keeps growing all over Indonesia and is adored by Indonesian people.

At a glance, campursari was formed in a straight and simple history. However, the musical mixing composed of some basic elements of karawitan, keroncong and pop music as it is today, is not easy and integrated. Undoubtedly, there are so many unheard sounds that are not always united in musical mixing, but in fact, they are part of music that can not be ignored.

In campursari, there is an ongoing power struggle that accompanies the new genre of musical hybrid. In a particular sense, it is the battle site between the dominant group and their strategies and tactics to avoid prevention, evasion or tacit resistance from the subordinates. The sound hybrid produced by various musical instruments not only makes campursari a musical phenomenon, but also has created a discourse as a result of the global process of what is "Javanese arts" or "Javaneseness."

This paper is part of the dissertation about the creation of arts that uses sounds and Sundanese traditional arts as its foundation. The new thing that writer gets out of this phenomenon is that the traditional music actually still has extraordinary energy and power which can be created into a monumental work.

\section{METHOD}

This research is qualitative with an interpretive-phenomenological thinking foundation that is subjective-truth oriented toward the research source. According to Alfred Schutz, the subjective experience is always in touch or interacts directly with the object being observed (Norman and Yvonna, 1995: 337).

This study is part of an artwork creation equal to a dissertation (S-3 Degree Program of ISI Yogyakarta) entitled Pakusarakan Kuring. The study results presented in this paper are part of the preparatory phase. This study uses descriptive analysis method through observation, information collection and direct delivery of ideas. The approach employed in this study is a qualitative approach. According to Bogdan and Taylor (1993: 30), in a qualitative approach, researchers observe and capture reality and 


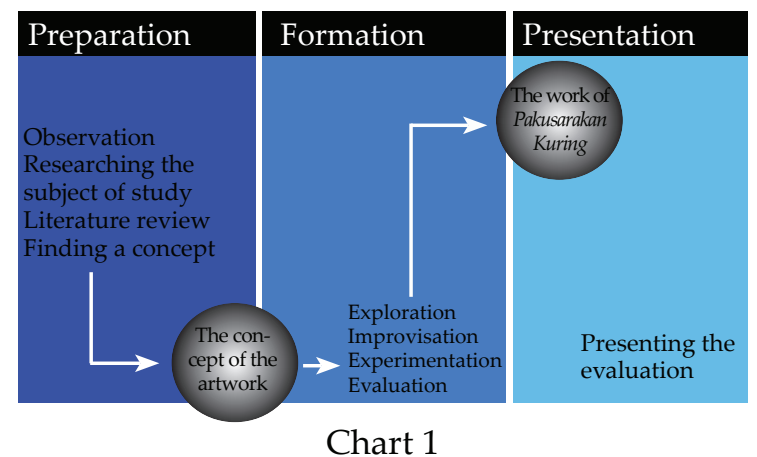

A Creation Scheme of Pakusarakan Kuring

examine the behavior of individuals, groups, and their daily experiences. Thequalitative approach is used because the study object is the Sundanese people's strategy to preserve their culture.

According to Strauss and Corbin (1994: 273), for a research that focuses on the disclosure of processes or mechanisms, a qualitative approach is relevant. To achieve the expected goals and to facilitate the research, steps of field preparation activities and field implementation. On field observations, interviews conducted are based on the problems being studied, findings on field study and literature study results. Data collection is done by in-depth interviews as the main data collection.

In this way, (in-depth interviews) data obtained can be more complete and comprehensive. In addition to the primary data obtained from observations and in-depth interviews, secondary data were collected through documentation.

\section{RESULTS AND DISCUSSION}

\section{Traditional Music Meets Modern Music}

If in the creative process traditional music instruments are only regarded as a medium, it causes the creation to seem fake, even though it still has novelty value. For example, the division of gamelan melodies is strange compared to Western music which always uses seven intervals in one octave. Gamelan has two different scales (laras): laras slendro has five intervals within one octave, while the laras pelog has seven different intervals within one octave. Thus, the effort of playing both laras in one melody system would be strange.

According to Bernard Dorl'eans (2006), the attempt to create works by bridging the differences between the two melodic divisions began in 1889. It was a commemoration of a hundred anniversary of the French Revolution. The country held a fair and the inauguration of Eiffel Tower. On that event, gamelan performance was shown right on the legs of the tower. The gamelan performance inspired a talented young composer Claude Debussy who was 27 years old at the time. What Debussy did in the context of transferring media can be said as an effort of bridging media.

Slamet Abdul Sjukur, when he was asked about Debussy and gamelan that many people thought as a hoax, said that Debussy never used gamelan in his works. Its sounds were never heard in his works like the detractors expect. A shallow expectation. A genius like Debussy was not interested in merely imitating gamelan. Instead, he captured its essence and made it his inspiration. Debussy compared the Sundanese gamelan with Palestinian music, which became the epitome of 16th-century polyphonic music (music composed of many melodies that sound at the same time, each has its own path without disturbing any other melody). The complicated Palestinian music, according to Debussy, is nothing compared to the subtle intricacy in the gamelan.

Furthermore, Damono (2012) formulated that from the theoretical point of view, it can be explained that it happens because of the interaction between media. There are two important concepts covered by this term: First, the vehicle is a medium that is used to reveal something. Second, the vehicle is a tool to carry or move things from 
one place to another. That movable "something" may take the form of an idea, a mandate, a feeling, or just an atmosphere.

At first, an artist can have a great idea of what he is looking for, but he then improvises, modifies, or even alters his original purpose completely before he finishes it. The artist is directed by various goals, but they change as he works. We can say that changing goals during the execution process may embody aesthetic forms to the materials used.

Several studies show changes in the art of tradition takes place in line with the development of cultural, social, and scientific discourses, shifting the perspective from tradition to modern and even to post-modern. In his research, Piliang (2007) stated that changes in traditional art are inseparable from the development of post-modern discourse, since in addition to opening the space of existence for the art of tradition, it is offering a new challenge to the concept of tradition. Based on conservative views, "tradition" is a form of work, style, convention or belief that is represented as a continuation of the past into the present. Tradition is something lasts (durable) or continuous from generation to generation, which is accepted as "a taken for granted," with no room in it for any interpretation. However, based on a more progressive view, tradition is seen as open to reinterpretation. Tradition is anti-radical change, but to some extent, it opens itself to transformation.

Any belief that opposes "change" but at a certain level tolerates transformation is called "conservative." Its main spirit is to converse (Honderich, 1990: 1). The principle of traditionalism is one of the main pillars of conservative belief, such as respect and strong attachment to the established habits and institutions, to retain everything that is familiar.

Furthermore, Piliang (2007) explained that in order to survive, traditional art today requires charm and appeal, such as creative innovations based on the tradition itself; on the other hand, making changes and innovations in tradition is the same as abolishing the tradition itself because tradition does not tolerate change, although it may transform. Traditional art faces this kind of paradox, wavering between the needs of making innovation and the demands of continuing the habit. Today, traditional art within the life of the public (non-traditional society) is no longer developed for repetition, reproduction or repetition of tradition, but for the discovery of its "new spirit," for example through the tendency of eclecticism, intertextuality, hybridity or irony, in which various elements of tradition combined eclectically, ironically and even contradictory. Tradition is not understood as reproduction but rather as production. Tradition as repetition is understood only within the traditional society itself, which has no concept of change, transformation, and future.

Piliang's opinion mentioned above seems to have conformity with what later develops in today's society. Today, most members of society consider that practicing or even recognizing traditional culture and artshave become obsolete. Many of them adopt modern or foreign cultures astheir styles. The development of modern technology has made traditional art less desirable. This can be seen from the enthusiasm of young people who prefer modern music to traditional music.

An effort to adjust to globalization in the field of traditional music instruments is to combine traditional music instruments with modern music instruments so that its existence can still be accepted in this era. For example, Man Jasad and his colleagues, assisted by the elders of karinding such as Abah Olot and others in the group Karinding Attack, have successfully spread $k a$ rinding to various groups of people. Another 
group adopting karinding is a band named Burgerkill (from Bandung). This band uses karinding in rock music. This group views karinding as a rarely used Sundanese traditional instrument. In addition to karinding, in Bandung, there is also punklung. Punklung stands for "punk" and calung, to name a punk group that has developed a Sundanese traditional music instrument named calung to express their works.

The same thing also happens in Sundanese karawitan, which is often collaborated with other music instruments. Karawitan is often performed to support other kinds of art, such as dance, to give illustration and accentuation. Karawitan can be performed independently, meaning that its presentation is only for the sake of musical expression and without any other artistic interest (Soepandi, 1995). Therefore, it is easy for musicians to develop it into other genres of music such as jazz and fusion as has been done by Krakatau Band.

According to Piliang (2007), another thing that has encouraged the development of karawitan (especially Sundanese karawitan) is the thought of repositioning traditional art that first appeared because traditional art has no place in modern art, which builds upon the mechanism of binary oppositions that separate cultures into two worlds, high and low culture. High culture is a culture that created on the basis of the spirit of progress, novelty, and transformation; while the low culture is a culture that relies on reproduction and imitation. Traditional art is considered to be part of a low culture that is considered to have no value of creativity, innovation, and novelty. The repositioning of traditional art is done by deconstructing binary oppositions and placing the position of tradition art parallel to other arts.

Efforts of repositioning traditional art in music development in the world could be seen from the developing discourse of world music. World music is a music cate- gory that includes a variety of different musical styles from around theworld, such as traditional music, quasi-traditional music, and music that mixes more than one cultural tradition.

In the later development, the term world music in the 1980s was often used as a marketing device/classification in media and music industry, as well as to classify types of non-Western music. There are several definitions as opposed to world music. One definition covers "all the music in the world," although this broad definition has made the word almost meaningless (Bohlman, 2002; Nidel, 2004). This term is also applied to all kinds of music that combine Western popular music genres with a lot of non-Western music genres, also described as folk or ethnic music. However, world music is not exclusively traditional folk music. This may also include peripheral pop music style. In summary, it can be described as "local music from out there," (Williams, 2004) or "someone else's local music" (Porter, 1995). This is a music genre with vague terms asthe increasing number of subgenres that fall under category world music to capture the trend of multi-ethnic music including elements of Western music.

The development of traditional art (such as in the Gamelan Festival of Yogyakarta and Krakatau Band) shows the reinterpretation of traditional art through new codes, to produce new compositions and meanings as well as the recontextualization of traditional art. The recontextualization of traditional art is done according to what is called "local spirit" (Piliang, 2007). This "local spirit" becomes the basis for developing the traditional music performances without considering the origin of the performer and the place where the art is developed. "Local spirit" (volkgeist), as described by Got Fried Herder, is the spirit that is expressed in speech, mythology, religion, folklore, art, literature, morality, custom, and law, which 
determine how the local people live, imagine, think, feel, and act, represented by the language mechanisms that unite individuals within their communities. In the traditional art, "local spirit" is then placed on the new territorial resulting the deterritorialisation process, namely the process of divesting artistic traditions from their origins.

\section{Development Strategy of Sundanese Karawitan}

The exploration of traditional percussion in music performance was done by $\mathrm{Gi}-$ lang Ramadhan who tried to combine the drumset with gongs and other traditional music instruments. All of these have been specially arranged by him. He also modified its pedals so that it can make some distinctive local sounds.

As the result, the music sounds unique because the rhythm of local music would be heard throughout the show. Among others are the Sundanese rhythm (West Java), Javanese rhythm, Balinese rhythm, Papuanese rhythm, Acehnese rhythm and the rhythms from other areas. Listening to this music is like being invited to enjoy the culture of each region. His work in the album Pagar Baya (2000) specifically explores a wide variety of percussion located in Indonesia. Although he did not specifically work on ethnic Sundanese percussion, as a drummer Gilang Ramadhan tried to adapt the rhythmic patterns that existed in the ethnic percussion of the archipelago played in his performance.

In a special interview Gilang Ramadhan explained that Indonesian society has been much influenced by outer cultures that can reduce and eliminate the culture of Indonesia. It is a pride for Indonesian people if Indonesian culture is known by foreign people, and widely performed in the global setting. Another thing concerning the culture of tradition that he mentioned was his desire to return to the culture of his origin. This desire then encouraged him to develop and explore Sundanese art in which he was raised. Many kinds of traditional percussionare unique and givethe inspiration to be developed in terms of form and rhythm. Gilang's rhythm patterns are influenced by his ancestors' religion, which is also embraced by society. The usage of Sundanese kendang has inspired Gilang to change his techniques of playing modern drums and to create ethnic drums that provide new patterns into drum performance, for example in the rhythm of sawah and genjring ronyok.

In terms of instrumentation, the drums' musical sounds are almost close to the sounds of Sundanese drums (kendang). The equation (substitution) of the sounds is as follow:

Bass drum: gedug Tom 2: katipung

Snare: kemprang, Hi-hat: kecrek, kenong and tambourine.

Tom 1: kutiplak Floor tom: gong

In terms of musical performance, the rhythm of sawah has a similar rhythmic pattern with the pattern of tepak mincid (model 1 and 2) in the playing of kendang as shown in the following example.
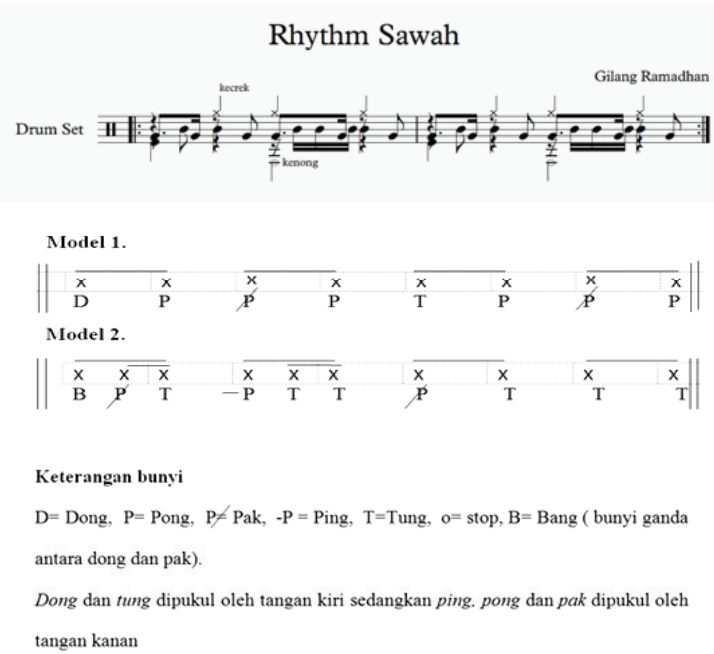

Album The Rhythm Of Reformation by Krakatau Band (2006), if you notice what is suggested by its title, offers percussion as the main menu. Some percussion instru- 
ments like genjring, terbang, rebana, kendang, dog-dog, ceng-ceng, kempli, jengglong, lodang, bedug, taganing, gondang, karinding, bonang, kempul, selentem, gong and certainly drums were presented in this album. The Rhythm Of Reformation is the album that including some Indonesian rhythmic patterns and percussion beat within jazz format.
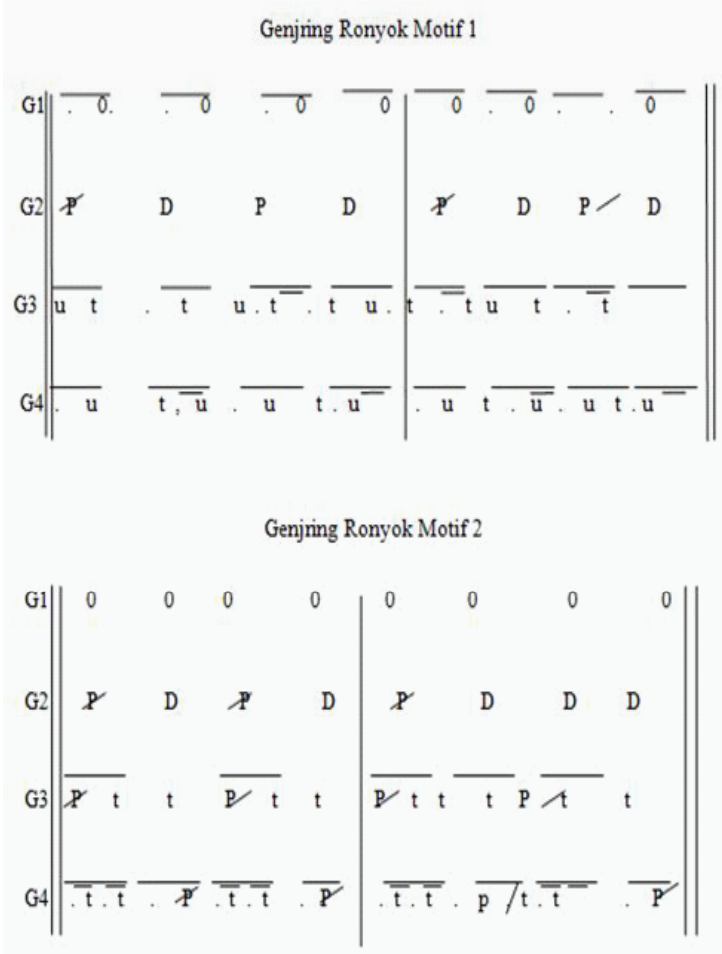

Description of the notation

$$
\begin{aligned}
& 0=\text { pong } \quad \mathrm{T}=\text { tak } \quad \mathrm{G} 3=\text { genjring } 3 \\
& \not=\text { ping } \quad \mathrm{G} 1=\text { genjring } 1 \quad \mathrm{G} 4=\text { genjring } 4 \\
& \mathrm{D}=\text { dong } \quad \mathrm{G} 2=\text { genjring } 2 \mathrm{U}=\text { tung }
\end{aligned}
$$

Genjring Party song is a song taken from art rhythm patterns of genjring ronyok from Subang, West Java. Genjring ronyok is an art with Islamic nuance. This can be seen from the history of genjring ronyok that was used as a medium to spread Islam in Kawali in 1842, along with the entry of seven Ulama as representatives from the Sultanate of $\mathrm{Ci}$ rebon. The spread of religion at that time was done through the medium of religious talk and art (Hafsari, 2011: 1). Genjring ronyok was originally known as genjring buhun tepak lima. The name was used because it used five genjring. But in the later development, this art also featured ten genjring and one drum. Thus, the name genjring buhun tepak lima was no longer used and was replaced by genjring ronyok. As for the name ronyok is taken from the way they use genjring that was played together in a group simultaneously that in Sundanese terms is known as dironyok.

Genjring ronyok is an art commonly performed in celebration events such as circumcision, marriage and thanking God for harvest time. The interesting thing to observe from this work is the very complicated music. First of all, the musical scales are built on elements of Sundanese pentatonic which may be unusual for the ears of jazz music lovers. In addition, as their music chants into improvised parts, the used scales no longer sound like pentatonic music, which may still be easy to listen. At that point, the scales they use are transformed into "microtonal" scales because they combine slendro, pelog, madenda, and mataraman scales at once in an octave. The consequence of the combination of the Sundanese scale system is the change in the height of each tone in their instrument that is no longer based on the pitch.

In the article entitled Penampilan Krakatau in Toronto Jazz Festival, Franki Raden concluded that music played by Krakatau offers a new challenge, not only for the listeners and soundman (who may not be familiar with the traditional instruments) but also for the players of Krakatau themselves. By relying on original Sundanese pentatonic, their music is in the area of heterophonic (multilayer) gamelan music. Meanwhile, their songs were created on the Western homophonic basis. Krakatau was aware of this, but they did not seem to have found the right solution yet. The current sound of Krakatau music is a kind of dualism. While playing the melodic part of the song, their music becomes pentatonic music (slendro 
and pelog) of thick Sundanese. However, upon entering the improvised section, their music turns into a very floating "just intonation" jazz music (not modal, not tonal, and not even atonal).

\section{CONCLUSION}

Traditional arts that are almost extinct or have been abandoned by their patrons can be maintained or revived through revitalization. As a concept, the revitalization not just "bring back to life," but rather the most important thing is to restore the collective memory of the community to fill the "void" caused by the "lost". Through these activities, one can see possibilities as references and representation of cultural events. Revitalization will be important when "something lost and forgotten" is beneficial to people's further lives. That means the revitalization of traditional arts is an effort to enable it to respond the changes of time.

Traditional art today is not just developed to celebrate the past (to repeat). Present society has changed and greatly appreciate the heterogeneity, fragmentation and cultural pluralism. The concept of the change in the tradition can be interpreted as an act of changing the substance of an object, stripped of all aspects of inherent feature without leaving traces of tradition to create something new. While the concept of transformation in the tradition does not change the substance, yet it is the process of repairing or improving some weaknesses found in the tradition.

At the present time, in the context of its existence, traditional art faces a paradox. On the one hand is to survive, on the other hand is to innovate and change the tradition, which is tantamount to erase the tradition itself. From the above description, it can be concluded that nowadays, showing appreciation to the tradition is not to do repetition and reproductionof tradition, but it is an attempt to find "new spirit" of tradition through the tendency of eclecticism, intertextuality, hybridity and, or, irony. Tradition is not understood as a repetition but reposition, not as reproduction but production. Tradition can be understood as a repetition only in traditional societies instead of in public in general.

In the world of art, many people think that modern arts would defeat the traditional arts. In particular, modern art is regarded to be easily accepted and favored by the younger generation. Because of that, the changes of time that demand modernization is a challenge for the existence of traditional art. Proponents of traditional arts, including their actors and patrons, need to immediately take strategies and effective measures to preserve the traditional arts.

Renewal (modernization) is not to be avoided, yet it should be used to update the traditional arts. In the artistic process, the flow of modernization and globalization are not taboos. These efforts are actually strategies in order to maintain the traditional arts. Many traditional arts can survive because they are adjusted to modernization and globalization. In the creative process, there must be creations and ideas development through various forms of expression.

From the observation of what has been done by Gilang Ramadhan, Dwiki Darmawan (Krakatau Band), it can be said that the efforts of modifying and changing media in performing arts, especially Indonesian traditional music, are not something new. They have developed over time. What Gilang and Dwiki have done can be regarded as attempts to give orput a nuance of tradition in their works. In the works they created, traditional art and traditional values are treated as local spirits. Another important thing is that there must be lots of traditional percussion instruments (especially in West Java) which are unique and inspiring to be developed in terms of musical form and rhythm. 


\section{Bibliography}

Atik Soepandi

1977 Khazanah Kesenian Jawa Barat. Bandung: Pelita Masa.

1995 Ragam Cipta: Mengenal Seni Pertunjukan Daerah Jawa Barat. Bandung: CV Beringin Sakti.

\section{Bernard Dorleans}

2006 Orang Indonesia dan Orang Perancis dari Abad XVI sampai dengan abad XX, Judul asli Les Francais et I'Indonesie. Jakarta: KPG (Kepustatakaan Populer Gramedia).

Bogdan, R., and Taylor, S.

1993 Kualitatif Dasar-Dasar Penelitian, (A. Khozin Afandi, Penerjemah ). Surabaya: Usaha Nasional.

Bohlman, Philip

2002 World Music: A Very Short Introduction, ISBN 0-19-285429-1 (tanpa keterangan penerbit).

Brouhgton, Simon

1994 World Music, The Rough Guide. London: Publisher by Rough Ltd, Merces St.

Csikszentmihalyi, Mihaly

1996 Creativity, Flow and the Psychology of Discovery and Invention. London: Harper Collins Publisher.

Deni Hermawan

2002 Etnomusikologi, Beberapa Permasalahan dalam Musik Sunda, Musik Sunda Patareman: Konsep Garapan, Proses Perwujudan, dan Perkembangannya. Bandung: STSI Press.

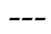

tuk Kreativitas Tembang, Laporan Penelitian STSI Bandung.

Denzim, Norman K. and Yvona S, Lincoln 1995 Handbook Of Qualitative Research. London: Sage.

Fitri Indra Hafsari

2011 Kesenian Genjring Ronyok pada Acara Maulid Nabi Muhamad SAW di DesaSelapajang Kecamatan Kawali Kabupaten Ciamis. (Skripsi, tidak dipublikasikan) Bandung: Universitas Pendidikan Indonesia.

Honderich, Ted

1990 Conservatism. Westview Press.

Mack, Dieter

2004 Musik Kontemporer \& Persoalan Interkultural. ARTI.

Menuhin, Yehudi

1980 The Book of Music. London: Macdonald Educational Ltd wipgjd.

Ramachandran V.S

2012 The Tell-Tale Brain. London: Windmill Books.

Sapardi Djoko Damono

2012 Alih Wahana. Jakarta: Penerbit Editium.

SP. Soedarso

1991 Tinjauan Seni Sebuah Pengantar Apresiasi. Yogyakarta: Saku Dayar Sana.

Strauss, A\& Corbin, J.

1994 "Grounded Theory Methodology: an Overview": Denzim, N.K. \& Lincoln, Y.S (eds), Handbook of Qualitative Research, pp. 273 - 285. London; Thousand Oak: Sage.

Yasraf Amir Piliang

2007 Seni Pertujukan Tradisi dalam Peta 
Seni Post Modernime. Jurnal Panggung, Vol.17 No.2 June-September 2007 .

Webtography:

Nidel, Richard

2004 World Music: The Basics. ISBN 0415-96801-1.http://www.sibetrans. com/trans/a300/new-perspectiveinethnomusicology-a-critical-survey?lang=en

Porter, James,

1995 Trans, Revista Transcultural de Musica, (ISSN 1697-0101 Vol.1 1995), "New Prespectives in Ethnomusicology: A Critical Survey",http:// www.sibetrans.com/trans/a300/ new-perspectives-inethnomusicol ogy-a-critical-survey?lang=en

Williams, Jack

"Robert E. Brown brought world music to San Diego schools The San Diego UnionTribune". Signonsandiego.com. Retrieved 2010-04-24., Elder, Bruce. All Music Guide,
fRoots magazine, quoted in N'Dour:2004] http://warisanindonesia.com/2012/04/ slamet-abdul-sjukur-hubungan-gelap-debussy-dengan-gamelan-jawa/ diakses tanggal 10 Agustus 2015 jam 24.20

http://zalgie.blogspot.com/2010/07/karinding-attack-band-melestarikan.html diakses tanggal 10 Agustus 2015 jam 23.22

http://ww w.hand made.tobucil. net/2010/11/punklung-antara-resistensidan-tradisi.html, diakses 16 Agustus 2014 www.krakatau.net di akses pada 23 Maret 2014

Discography:

Pager Baya, Gilang Ramadhan, Produksi GRSD, 2005

Rekaman Genjring Ronyok, Subang (Dokumen Pribadi).

Krakatau, Album Rhytm of Reformation, Produksi Musik Kita Jakarta. 